UDC 811.112.2:81'.374.45

https://doi.org/10.31548/philolog2020.04.027

\title{
FORMS OF ADDRESSING AND THEIR FEATURES IN MODERN GERMAN
}

\author{
G. V. FOMINA, PhD in Philology, associate professor, \\ National University of Life and Environmental Sciences of Ukraine \\ E-mail: haljafo9629@gmail.com \\ https://orcid.org/0000-0001-9829-9351 \\ N. M. KOSTRYTSIA, Doctor of Pedagogy, professor, \\ National University of Life and Environmental Sciences of Ukraine \\ E-mail: n.kostrytsia@gmail.com \\ https://orcid.org/0000-0002-7029-7829 \\ O. M. LYTVYNIUK, PhD in Philology, senior lecturer, \\ Kamianets-Podilsky Ivan Ohienko National University \\ E-mail: lytvox@gmail.com \\ https://orcid.org/0000-0002-4428-9892
}

\begin{abstract}
The article analyzes the features of addressing forms in German. There are pronouns used in the formation of imperative forms, in particular du, ihr, Sie which are considered. The historical transformation of polite pronouns in German-speaking culture is studied. Attention is focused on the functioning of various forms of treatment in various spheres of modern life. The diachronic characteristics of separate lexemes, the stages of their development and the change of the primary meaning are traced. The authors consider the national specifics of German forms of addressing, features and difficulties that may arise in intercultural communication, mistakes at the lexical, grammatical and culture studying levels. Lexemes in different professional fields which are used to attract attention are analyzed separately. A historical review is carried out to establish the initial stages of formation of the category of politeness. The role of lexemes Frau, Herr, Fräulein, Kollege in different periods of society formation is determined. Regional features of treatment, addressing someone in the private sphere are analyzed. It is stated that the forms of addressing include nominations that are related to social status, professional activity, gender and age, mostly they reflect the relationship between members of society and the social hierarchy. The Germans attach considerable importance to the ability to behave themselves in society. The authors draw attention to the fact that the forms of addressing in the Austrian and Swiss versions of the German language are formed due to the influence of historical circumstances. The ability to properly usage of various forms of referring to people opens wide opportunities for understanding other cultures, their practical implementation in the professional sphere. Such knowledge gives an impetus to understand the peculiarities of their own culture. To sum up, the forms of addressing in German speaking societies have been changed synchronically and diachronically.
\end{abstract}

Keywords: forms of addressing, a form of politeness, lexems, diachronic analysis, addressee pronouns.

Problem setting. The language reflects the national consciousness of a certain folk. In particular, in order to master the German language, you need to look at the world through the eyes of an average German. The ability to address someone correctly is an important component of intercultural communication. Therefore, there is no doubt that the first step toward the understanding of another culture bearers is to trace how people treat each other. German personal pronouns ich, sie, er, es, du, wir and so on are a key element to succeed in communication (formal or informal). The consequences of an inappropriate communicative act in relation to the interlocutor can be embarrassing, unpredictable, furthermore they might be offensive or failing.

Analysis of recent researches and publications. According to S. G. Ter-Minasov's point of view, mutual understanding in all aspects (linguistic, socio-cultural, axiological) and many others is the basis and purpose of the dialogue of cultures [6]. Units of language etiquette are forms of drawing attention, greetings, acquaintances, farewells. Addressing someone is aimed at establishing a contact 
between interlocutors, so the study of forms of addressing in synchronic and diachronic sections is of some great importance for understanding the foreign language culture. This problem has gained some attention of such linguists as Alpatov V. M. [1], Velychko N. M. [2], Poberezhnyk N. O. [4], Ponomarenko V. P. [5].

Objectives setting. Forms of referring to people include nominations that are related to social status, professional activity, gender and age, mostly they reflect the relationship between members of society and the social hierarchy. There is a clear line between $d u$ (singular, familiar you) and Sie (plural, formal you) in social situations. The Germans give great importance to the ability to behave in society. And many scientists still consider an article «Über den Umgang mit Menschen» to be a classic etiquette manual. The authors of the article focuse on the historical and social aspect of the development of forms of addressing in the German language space.

At the grammatical level, the phenomenon of etiquette is demonstrated by the form of the polite pronoun Sie that has 3 forms. To tell which is to notice the verb ending and/or the context where it is used. If we turn to the history of the German language, we can note that the ancient Germans had two addressee pronouns: $d u$ that was used to address one person (addressee) and ir (modern ihr) - to address two or more interlocutors. There was no form of politeness. With the development of society, this type of pronouns is assigned the function of expressing social relations between interlocutors. The representatives of the highest hierarchical level used ir, the representatives of the lower strata used $d u$ [2].

Socially marked, polite attitude towards another person originated from the Latin Pluralis majestatis. Roman emperors exalted themselves in the first person plural («we»), emphasizing their importance. Initially, the use of this pronoun was a type of characteristics of the courtiers' communication with the emperor then it was spread to the communication of the nobility with each other and only then it became typical for any situation of social inequality. The higher nobility required respectful treatment particularly in the plural to emphasize their superiority.

Other languages also borrowed the polite addressing people in the second person plural from Latin. The heterogeneity of the social structure of society led to coexistence and competition in the German-speaking environment of the 17-18th centuries. There were several forms of polite addressing: ihr, er / sie (third person singular, masculine and feminine), Sie (third person plural). At the same time, the pronouns Er / Sie are claimed to be used as the most polite form. However, at the end of the 17th century the aristocracy began to use these pronouns in a situation of contempt and indulgence, offering them as an alternative a respectful address in the third person plural - Sie, which is derived from nominal addresses such as Euer Gnaden haben. At the same time the form Ihr continued to be used. Later Jakob Grimm opposed the spread of Sie addressing, he called it as «a shameful stain in the German language». Although, this pronoun turned to be the most acceptable form of polite communication for the Germans.

In modern German there are three addressee pronouns: $d u$ - to express trust or solidarity when addressing one person, ihr - the same meaning, but addressing was for two or more people, Sie defines a formal position or distance when addressing one or more recipients. Generally the Germans prefer the pronoun $d u$, regardless age differences.

In private life only an elderly person can offer to communicate with $d u$ - regardless of whether it is a woman or a man. At work places everything depends on age or gender and the service hierarchy as well, because only the boss has the right to offer a subordinate to transfer the communication to «you» (singular) [8].

Communication using $d u$ is also possible between managers of the same level, for example heads of two departments can use this form only when they meet face to face in the absence of subordinate staff. And the one who works longer in the company can offer the usage of «you» (singular).

There is so called the "Hamburg you» while addressing a person and it is when one calls the first name and "you» (plural) in Germany. This form does not make communication very formal, but at the same time it does not make it familiar. Hamburgers adopted it from the Americans. As a rule, a senior can afford to address his subordinate in this way, but in no case vice versa. It is possible to contact with service workers if only their names are indicated on their uniform badges.

At the same time there is the "Munich you» - the complete opposite of the "Hamburg you». This is a form when a person is addressed with one's last name and "you» (singular). For example: «Müller, komm zu mir». This is how the citizens of the Bavarian capital often communicate with each other. Cashiers of 
German supermarkets have come up with an even more unusual form of treatment: «Frau Müller, sieh mal, wie viele das kostet» - can be heard in the hall of any trading center.

At the present stage the Germans are much more likely to use the form $d u$ than they used to. In the youth environment, addressing "you» (singular) has been considered the norm. More familiar "you» (singular) migrated to advertising business: in this way manufacturers flirt with the consumer. "Do you still exist or do you live?» such an advertising slogan was invented in the German branch of the Swedish furniture concern Ikea.

Du addressing in companies are becoming more and more noticeable. Many executives address their partners, clients, or employees with $d u$. First of all it is connected with communication on social sites (Facebook, Telegram, Twitter, and so on). The web platforms introduce the tone of communication. German studies show that a significant number of world-renowned companies (Coca-Cola, Rügenwalder Mühle, Yello Strom, Sony Deutschland, Samsung Mobile Deutschland, H\&M, Douglas, Joop, OBI, Hornbach, Bosch, Rodenstock, Galeria Kaufhof, ADAC, Tipp24, Audi, Adidas) addresses their consumers ant customers as "you» (singular) [3]. However, many banks and insurance companies prefer Sie-treatment.

The vast majority of expensive fine goods manufacturers do not allow brotherhood or familiarity. "Take a test-drive in our car!» a voice says in a commercial for the German automobile concern BMW while using you plural.

In certain situations the appeal to "you» (singular) can be simply offensive (in particular, the situation with the policeman's lawsuit against Dieter Bohlen; the cause for the lawsuit was that the showman insulted the police and undermined the constitutional principles of the state by having treated this person inappropriately). According to the law it is only possible to use "you» (plural) in official communication while addressing a police officer in Germany.

On public radio broadcasting there is solely "you» (plural) as a striking example of the use of $d u$ by contemporary Germans, where the host of the program, guests and callers address each other using "you» (singular), as well as many talk shows do the same on television and interviews in the press.

A reputable firm usually offers its clients to choose a convenient form of communication.
So, for example at registration of the personal statement letters the Goethe-Institute offers the clients to choose the form of addressing for communication i.e. they are given the choice.

Actually the Germans point out a number of «traps» that may come to the fore in the process of communication [8]. Trap number one. After a corporate party, where communication took place with the $d u$ form, you should not say "you» (singular) to the boss. It will be advisable to wait for a person's appeal, where the boss is on the highest professional step or one should choose a neutral form of addressing. Trap number two. The initiative to switch to "you» can never come from a subordinate (even if somebody is much older than the boss). Trap number three. In no case can you definitely refuse the offer to switch to "you» (singular). This will humiliate the opponent. It is better to offer to learn more about the interlocutor.

Addressing used by family communication and between loved ones reflects personal relationships. Most students tell their parents $d u$. The popularity of $d u$ testifies to the friendly relations between grandchildren and grandparents, the form Sie is unpopular. Even it is thought to be out-ofdatedfrom the point of view of young people. A small number of young people use polite Sie in communication with their parents. Most adolescents address grandparents with $d u$, only a small proportion of respondents use the addressing Sie. The age range varies when teenagers go from $d u$ to Sie in family and relative communication (from 11 till 18 years old). Nowadays young life partners and married couples use usually $d u$ in communication, in the case they use the addressing Sie then it sounds ironic unless there is a certain reason.

Treatment is generally regulated in academic and school environments, political circles, law enforcement agencies, as well as in the church sphere. Today's students often use the addressing $d u$ and one's first name when referring to other students, only a small percentage of people use Sie. When addressing unfamiliar students, most speakers prefer $d u$, while the others prefer Sie. If students are different in age, it is possible to use polite Sie. The student movement of the 1960 s was a signal of social transformation. Sie was perceived in student circles as something "strange, weird". The progressive part of the students as well as left-centered associations preferred turning to the usage of $d u$. However, the politely formal Sie has stood the test of time, and modern students turn to professors of respectable age with Sie and with the words Frau / Herr in combination with a surname or a 
title. When addressing young professors, a small number of surveyed students use the form $d u$ and the first name alongside with the one mentioned above [2]. Modern students and teachers use mostly trustful $d u$ in communication with each other, which is an indicator of partnership and cooperation in the school. Students ought to address teachers with Sie which should show some respect.

The regional features of the appeal have developed historically and are generally conservative. Thus, a special variant of standard personal pronouns is the Berlin Se; a specific feature is also the usage of Sie / Er pronouns in appeals to lower-ranking individuals.

In Munich it is common to use the addressing $d u$, which is combined with other official forms. Hamburg citizens use the addressing Sie, combining it with the names of interlocutors. A characteristic feature of the (colloquial) speech of the Rhineland is that the appeal to the Ihr often acts in a "universal" role, ie as a single plural form. A typical Bernese polite addressing someone is Dihr $(=i h r)$. In addition in the German-speaking cantons of Switzerland, relics of the "polite» Ihr have been preserved as an appeal to one person.

Separately, it can be noticed that the most common form of addressing acquaintances is Herr ..., Frau .... (titles Herr and Frau appeared in the early 17 th century in noble circles). In official communication some preference is given to - Meine Damen und Herren! Mein Herr, Meine Dame are used to refer to strangers. Meine Herren sounds emphatically businesslike in the male audience! (Meine) Herrschaften phrase is ironic and it sounds as out-of-date, old fashion! Initially, only representatives of the nobility had the right to respectful treatment of Herr, Frau, Fräulein. Descendants of German nobles were called Junker. The noun Frau comes from old-high-German vrouwe, and middle-high-German frouwe and was associated with the name of the goddess Freyja, as well as with the name of the masculine god Freyr. The word had the primary etymology as der Erste, Vorderste (Gothic frauja, asächs. froio, aengl. friega) [7].

According to this origin, the lexeme had the meaning die Herrin, die Dame von Stand (the expression gnädige Frau functions today as a remnant of this etymology). Regarding the Herr nomination, there were senior and dominus appeals during the Middle Ages. Moreover, Herr is formed according to the model of senior (with the meaning of älter).
It should be noticed that Frau's addressing requires a surname. It means that the phrase "Guten Tag, Frau!» will be inappropriate and will sound like «Hello, baby!» Bastian Zeek showed how the Germans actually avoid such a tricky trap. To start a dialogue with a stranger, you should say «Entschuldigen [Sie]!» or «Hello!» and make a pause. You may be able to do well without Frau throughout the conversation.

If we draw a historical parallel, it will be worth mentioning that by the middle of the twentieth century it was accepted to use the word Fräulein in the addressing young unmarried girls, which originated in the 20th century: («Fräulein (seit dem 12. Jh. bezeichnet mhd. vrouwelīn als Verkleinerungsbildung zu vrouwe besonders die unverheiratete junge Frau vornehmen Standes; die Bezeichnung war bis ins 18./19. Jh. dem Adel vorbehalten und wurde dann auch auf bürgerliche junge Frauen ausgedehnt; danach galt sie allgemein für die unverheiratete [jüngere] Frau»). In February 1971, such an official form of appeal was abolished, as in the 1960s feminists argued that the word had a neutral gender, and the difference between the words Fräulein and Frau led them to believe that only a married woman became a full member of a society. It was used as an age characteristic of girls in rural areas. Furthermore it was associated with premarital sexual experience and it was considered to be offensive in 1970-80. The married girl was called juncfrouwe; the girl of simple origin was associated with the name maget [7], which later became "maid" (Dienstmagd) and was replaced by Fräulein.

Another argument for avoiding such word usage was that there was no equivalent for naming a young unmarried man - young men as well as married men in Germany were addressed in the same way - Herr. The diminutive suffix -lein emphasized, according to feminists' opinion, the immaturity, inferiority of girls.

However, in Germany significant decreasing of Fräulein addressing turned out to be more difficult to be reached than it was expected. Currently this word is mostly used in an ironic context. For example there is a nostalgic sign on the wall of a hairdressing salon, where the owner deliberately calls herself the old-fashioned Fräulein. This is how strict parents sometimes turn to their mischievous young «girls» wanting to upbring them.

The social status of the interlocutor is emphasized in official communication by the 
nouns Herr / Frau Direktor / Doktor / Professor (in)! The words Sehr geehrter Herr N! Wir dürfen Sie herzlich begrüßen ... sound solemn, polite and friendly!

A close acquaintance is approached by (Mein) lieber Kurt! The adjective Liebe(r) is used when greeting, entrusting an important task to a well-known person in formal and informal communication!

An obsolete form with an ironic tinge is Gnädige Frau addressing! The use of the addressee after the pronoun Sie emphasizes the high degree of respect Sie, Herr Präsident, haben eine wichtige Entscheidung getroffen! Liebe Kolleginnen und Kollegen! is used to speak to the audience in the professional sphere. Without an adjective, this form creates an atmosphere of professional closeness: Kolleginnen und Kollegen! The participants of the meeting are solemnly greeted by Liebe Freunde! Junger Mann! Junge Frau! emphasize the age difference between communication partners!

Mutter! Vater! Can be heard in communication with parents without emphasizing warm feelings! Vati / Papa / Papi! Mutti / Mama / Mamil show kind treatment of children to their parents in informal communication. When there is a kind appeal to grandparents then ones can use Opa / Opi! Oma / Omi! (Neutral: Großmutter! Großvater!). Between brothers and sisters, mostly of young age, you can hear Brüderchen! Sisters! Tante Frieda! Uncle Anton are mostly used to refer to other relatives of a family! [9].

Nowadays the most common nominal forms of addressing parents are Papa / Mama, while until the 1960s almost «neutral» Vater / Mutter (with the diminutives Vati / Mutti) predominated; at the same time, a small number of respondents address their parents by name, and the modern colloquial names Doc, Boss, Vize, Paps, Daddy (to the father) and Mutsch, Muschka, Mimse, Mom, Mum (to the mother) also look uncommon and they are used eventually. Nicknames are indicative, affectionate names and abbreviated names are used to serve as addressing people. The choice of appeals depends on family traditions, upbringing, preferences and the type of activity done by participants of communication. A special place is occupied by the forms used in communication between couples and spouses. They reflect the relationship and character of the partners. In particular, Kleines, meine Liebe, Herzchen, Liebling, Schatz, as well as the latest Darling [2]. From the point of view of gender linguistics the forms of appeals to women are specific.

Forms of addressing in the Austrian and
Swiss versions of the German language are shaped due to the influence of historical circumstances. Austrians tend to use titles, additionally their characteristic feature is the attempt to maintain a certain distance in communication. In Switzerland, it still retains the functionality of contacting Fräulein. The Swiss pay less attention to the usage of academic titles and other ones, which is the way of the manifestations of the public life democratization.

The waiter is usually referred to as Herr Ober, ie. "the one who is in charge». But the waitress is not addressed like that (here the neutral Hallo! is used) that is because the phrase Frau Oberin is used to called only the abbess of the convent.

The religious sphere is an example of a conservative hierarchical system and addressing is accordingly regulated depending on the denomination. To a lesser extent this applies to the Protestant church - in the address the rank (Bischof, Kirchenpräsident, Vikar) can be combined with one's surname and name. Respect as a component of etiquette plays an important role in the spiritual realm.

During the existence of the GDR,such characteristic forms of treatment as Genosse and Freund were used. However, Kollege / Kollegin addressing were the most common. Another possibility was to use these forms in complex names such as Parteifreund.

In academic circles, the legal sphere, political parties, the church, the police and the army, as well as schools, modern nominal forms of address are regulated, indicating the professional and social status of the addressee.

Innovations in the field of addressing people were reflected in the German vocabulary edition Duden. In particular, this is the so-called "asterisk». It is a * sign which is used to denote both sexes when addressing several people at once in writing. For example: liebe Künstler/innen. The editors of Duden's dictionary believe that the new terms in their dictionary should reflect the current political debate, environmental issues, and gender equality.

Conclusions and suggestions. Thus, some of the most significant features of national cultures are reflected in the sphere of addressing people. The ability to properly use various forms of addressing opens wide opportunities for understanding other cultures, their usage in the professional sphere. Such knowledge gives an impetus to understand the 
peculiarities of their own culture. As it requires not only knowledge of grammatical norms and the ability to use them correctly but it also

\section{Список використаних джерел}

1. Алпатов В. М. Категория вежливости В современном японском языке. М.: Либроком, 2009. 152 с.

2. Величко Н. М. Форми звертання та мовленнєвий етикет (на матеріалі німецької мови). Наукові записки. Вип. 153. Серія: Філологічні науки (мовознавство). Кропивницький: РВВ КДПУ імені Володимира Винниченка, 2017. С. 356-357.

3. Зачепа І. М. Звертання на ти / ви в сучасній німецькій мові (культурологічний аспект). https://er.nau.edu.ua/handle/NAU/15556.

4. Побережник Н. О. Категорія звертання на «ти» / «ви» у сучасній німецькій та українській мовах. Наукові записки. Філологічні науки. Т. 3. Чернівці, 2010, 118-120.

5. Пономаренко В. П. Еволюція засобів звертання в індоєвропейських мовах: компаративно-типологічний аспект. Автореферат дисертації на здобуття наукового ступеня доктора філологічних наук. Київ, 2010. 35 c.

6. Тер-Минасова С. Г. Война и мир языков и культур: вопросы теории и практики. Учеб. пособие. М.: АСТ: Астрель: Хранитель, 2007. 286 с.

7. Das Bedeutungswörterbuch. Neu bearbeitete und erweiterte Auflage. Herausgegeben von der Dudenredaktion. Band 10. Dudenverlag. Mannheim Leipzig Wien Zürich. 1152.

8. URL:https://www.dw.com/ru/вы-мне-нетыкайте-особенности-немецкого-этикета/а16513975

9.URL:http://startdeutsch.ru/poleznoe/razg ovornik/249-obrashchenie-v-nemetskomyazyke

\section{References}

1. Alpatov, V. M. (2009). Katehoria vezhlivosti $v$ suchasnom yaponskom yazyke. [The category of politeness in modern Japanese]. Moscow : Lybrokom. 152. demands country study skills and their appropriate application and implementation.

2. Velychko, N. M. (2017). Formy zvernennia ta movlennievyi etyket (pro materialy nimet'koyi movy) [Forms of address and speech etiquette (based on German material)]. Naukovi zapysky. Seriia: Filolohichni nauky (movoznavstvo). Kropyvnytskyyi RVV KDPU imeni Volodymyra Vynnychenka,Vol.153, 356-357.

3. Zachepa, I. M. Zvernennia do ty / vy v suchasniy nimetskiy movi (kulturolohichnyi aspekt) [Addressing you in modern German (cultural aspect)]. https: //er.nau.edu.ua/handle/NAU/15556.

4. Poberezhnyk, N. O. (2010). Katehoriya zvernennya na «ty» / «vy» v suchasniy nimets'kiy ta ukrayins'kiy movakh [The category of addressing "you" / "you" in modern German and Ukrainian]. Naukovi zapysky. Filolohichni nauky. Chernivtsi, 3, 118-120.

5. Ponomarenko, V. P. (2010). Evoliutsiia zasobiv zviazku $\mathrm{v}$ indoievropeyiskykh movakh: porivnialno-typolohichnyy aspect [Evolution of means of address in Indo-European languages: comparative-typological aspect: the dissertation author's abstract on competition of a scientific degree of the doctor of philological sciences]. Avtoreferat dysertatsii na zdobuttia naukovoho stupenia doktora filolohichnykh nauk. Kyiv, 35.

6. Ter-Mynasova, S. H. (2007). Voyna i mir yazykov i kultury: voprosy teoryy i praktyky. [War and the Peace of Languages and Cultures: Questions of Theory and Practice]. Textbook. Moscow : AST: Astrel : Khranitel, 286.

7. Das Bedeutungswörterbuch. Neu bearbeitete und erweiterte Auflage. Herausgegeben von der Dudenredaktion. Diapazon 10. Dudenverlah. Manheym Leyptsyh Viden' Tsyurykh. 1152.

8. URL: https://www.dw.com/ru/vy-mne-netykayte-osobennosty-nemetskohoétyketa/a16513975.

9. URL:http://startdeutsch.ru/poleznoe/razgov ornik/249-obrashchenie-v-nemetskomyazyke.

\section{ОСОБЛИВОСТІ ФОРМ ЗВЕРТАННЯ У СУЧАСНОМУ НІМЕЦЬКОМУ МОВНОМУ ПРОСТОРІ \\ Г. В. Фоміна, Н. М. Костриця, О. М. Литвинюк}

Анотація. У статті аналізуються особливості фоорм звертання у німецькій мові. Розглядаються займенники, які використовують при утворенні фрорм імперативу, зокрема du, $\mathrm{ihr}$, Sie. Досліджується історична трансфрормація займенників ввічливості у німецькомовній культурі. Увагу зосереджено на ффункціонуванні фрорм звертання у різних сфрерах сучасного життя. Простежуються діахронічні характеристики окремих лексем, етапи їх розвитку та зміна первинного значення. Автори розглядають національну специфіку німецькомовних фоорм звертання, особливості та труднощі, що можуть виникнути у міжкультурній комунікації, 
помилки на лексичному, граматичному та культурологічному рівні. Окремо аналізують лексеми у різних профресійних сфрерах, що використовуються для привертання уваги. Здійснюється історичний екскурс для встановлення первинних етапів формування категорії ввічливості. Визначається роль лексем Frau, Herr, Fräulein, Kollege у різні періоди формування суспільства. Аналізуються регіональні особливості звертання у приватній сфрері. Констатуємо, що форми звертання включають в себе номінації, які пов'язані з соціальним становищем, профресійною діяльністю, статтю та віком, здебільшого вони відображають відносини між членами соціуму та соціальну ієрархію. Вмінню поводитися в суспільстві німці надають чимале значення. Автори звертають увагу, що форми звертання в австрійському та швейцарському варіантах німецької мови обумовлені впливом історичних обставин. Уміння правильно використовувати різноманітні фрорми звертання відкриває широкі можливості для розуміння інших культур, використання їх у професійній сфрері. Такі знання дають поштовх для усвідомлення особливостей власної культури. Таким чином, звертання у німецькомовному суспільстві зазнає змін на синхронічному та діахронічному рівні.

Ключові слова: форми звертання, форма ввічливості, лексема, діахронічний аналіз, адресатні займенники. 